
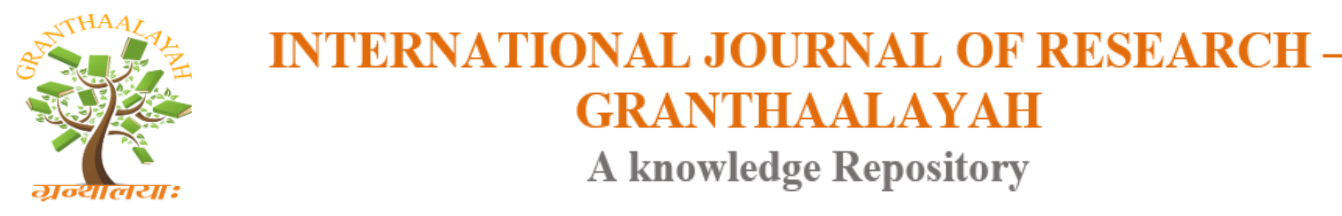

DOI: 10.29121/granthaalayah.v6.i3.2018.1499

Management

\title{
A STUDY ON THE IMPACT OF BUSINESS NEWS ON INVESTORS' DECISION
}

\author{
Prof. Divyang J. Joshi ${ }^{* 1}$ \\ *1 Assistant Professor, Parul Institute of Management and Research, Parul University, Baroda, \\ Limda-391760 (Gujarat), India
}

\begin{abstract}
The movement of the share price is always being the interesting topic for the researcher. The growing researches focus on the impact of bonus share announcement, stock split, right share, earning announcement, dividend announcement, and business announcement. There are more than 500 papers has been published in known journals which confirmed that stock prices react to news (Kothari and Warner (2006). But they are failed to integrate the sentiment of the published business specific news and its impact. Secondly, the studies which focused on long term, they failed to consider the potential problem of publication bias (Antweiler and Frank (2006). In this paper, the impact of Business specific News was measured with the help of sentiment analysis. Total 392 business specific news of 5 companies for 3 years were collected and analyzed. To check the impact of news, if any, the volume reactions were examined. The result indicates that there is an impact of news. Secondly, AAR and CAAR supported that informed investors can earn abnormal high return. The returns of positive and negative news were compared and it was concluded that there is no significant difference between AAR of positive business news and negative business news.
\end{abstract}

Keywords: Event Study; Sentiment Analysis; Market Efficiency; AAR; CAAR.

Cite This Article: Prof. Divyang J. Joshi. (2018). "A STUDY ON THE IMPACT OF BUSINESS NEWS ON INVESTORS' DECISION." International Journal of Research Granthaalayah, 6(3), 65-77. https://doi.org/10.29121/granthaalayah.v6.i3.2018.1499.

\section{Introduction}

The EMH states that (Fama 1991) the stock price adjusts quickly to the arrival of new information. In practice, it is observed that it takes time to adjust, which offers profitable opportunities to traders and investors. There are lot many types of research carried out on how financial market prices incorporate quantitative data. The traditional finance model tried to test EMH. Therefore, the majority of the studies are based on some hard facts e.g. operating and investing, mergers, acquisitions or IPOs, or financial variables, e.g., historical price data. But they have failed to integrate the sentiment of the published news and the impact of the news. The language used in a press release is likely to communicate values and sentiments that are not 
neutral (e.g., Katz 2001). The one of the many ways to study the impact of company-specific news on stock price is text mining. The text mining helps in sentiment analysis. Sentiment analysis encompasses the investigation of documents like news articles, message board postings or product reviews in order to determine their tone concerning a certain topic (Pang and Lee (2008)). The tone creates sentiments; the tone can be positive or negative (Tetlock (2007)). The systematic news analytics help in reacting in real time with due consideration of prevailing sentiment trend in given market (Hafez (2010)). For example, experimental evidence shows that analysts' annual earnings forecasts are influenced by the structure of managers' narrative disclosures, holding the information content of those disclosures constant (Sedor 2002). The quick reaction on the publication of company news offered an abnormal return. However, there is plethora of information available in the market which has to be analyzed properly to make favorable investment decisions. Recent studies supports that information in the form of news can be valuable sources to earn an abnormal return. The text-mining software helps in better understanding of news information.

This paper is arranged as follows. The second part provides an overview of literature regarding sentiment analysis and stock market prediction. The third part focuses on the objective of the study. Research methodology and data analysis and interpretation are covered in part fourth and fifth. The sixth part concludes with the conclusions and scope of further studies.

\subsection{Literature Review}

Sprenger and Welp (2011) had investigated the market impact of different types of companyspecific news events on S\&P 500 stock price. They have collected live twitter news to understand the immediate reaction of the investors. The news has been classified as positive or negative news by applying computational linguistics methods. The news had been collected from January $1^{\text {st }}$ to June $30^{\text {th }} 2010$, six months, and limited to 140 characters. They collected 439, 960 stock specific news and analyzed them through machine learning package to know the sentiments of the news. The news was classified in 5 heads, i.e. Corporate Governance, Financial Issues, Operations, restructuring issues, legal issues and technical trading. They found that market reacts differently to different types of news events. Positive news offered more abnormal return before the event compared to negative news. Robertson, Geva and Wolff (2006) had investigated about how the US, UK, and Australian markets incorporated all the real time news. The news and stock-database of 286 stocks were collected from the S\&P 100, FTSE 100, and ASX 100 indices from the $1^{\text {st }}$ May 2005 to $31^{\text {st }}$ of August 2006. The time series lognormal return of prices and volume were also measured. They found the changes in ticks' time series, which implies that the market is reacting to the news. They found strong evidence that the stock market did react to real-time news and fraction of news were responsible for the most significant market reactions.

Majdalany and Henderson (2013) have downloaded and studied 124 annual reports of publicly listed companies of UAE exchange. Each reports were codified with the help of QDAMINER 4 and WORDSTAT 6. They codified 6 Intellectual Capital categories like Human Assets, Relational Assets, Structural Assets, Human liabilities, Relational Liabilities and Structural Liabilities. Considering all 6 categories as Independent variable and ROE as the dependent variable, multiple regression analysis was applied. The result provides $\mathrm{R}^{2}=0.825$. It means, 
$82.50 \%$ of the variation in ROE is justified by the variation in the independent variables. Gyozo Gidofalvi (2001) found the predictive power of the stock price by estimating the short-term stock price movements using 20 minutes before and 20 minutes after financial news articles become public. To know the sentiment of the article, a naïve Bayesian text classifier was used.

Davis, Piger and Sedor, (2006) had collected 24,000 earning press releases from PR newswire for the period of 1998 to 2003. They applied a dictionary based content program, DICTION. They applied multivariate regression model for explaining future performance and found that the market responds positively to the amount of optimistic language contained in earnings press releases and a positive incremental market response to the unexpected portion of the net level of optimistic language in the earnings press release.

P. Srinivasan (2010) tested the random walk hypothesis on the Indian market. Total 83 stocks were selected from 11 different sectors and applied Augmented Dickey-Fuller test and PhillipsPerron test. He concluded that Indian market does not support random walk hypothesis. That provides an opportunity to the traders for predicting the future prices and earning abnormal profits. Adrian Wai Kong Cheung (2011) had studied the impacts of inclusions and exclusion of 139 stocks in Dow Jones Sustainability World Index during 2002-2008. The event study was applied in the window from 15 days before announcement day and 60 days after days of change. The impact was measured in terms of stock return, risk and liquidity. The study concluded that on the day of change, inclusion/exclusion of stocks faced significant but temporary increase/decrease in stock return but not had any significant impact on stock return and risk.

Michael Siering (2012) applied two-stage approach. He used text mining for the news information and then did sentiment analysis to predict the impact of company-specific news on the stock price. He collected 2,401 news articles of the 30 companies of DAX for the 2 days. He found the positive and negative words referring H-IV-4 (Harward IV-4) classification dictionary. They classified the news stories in positive, negative and neutral and used Support Vector Machine. He found and concludes that the combination of text mining and sentiment analysis can improve stock return predictions. Tetlock (2007) analyzed the sentiment of a daily wall street journal by using the General Inquirer's Harvard-IV-4 classification dictionary. He classified each word of the column according to its sentiment. He classified words in pessimist and optimist. His study found that high pessimism leads to decline in stock price.

Chiang (2010) used a computational text-scoring method to uncover investors' behavioral responses to the negative news. He calculated the sentiment score of 1645 news with the help of General Inquirer content analysis software and found that high negative news scores do not necessarily predict negative abnormal returns in the S\&P 500 across a 1-day to 5-day window. Schumaker, Zhang and Huang (2008) investigated the pairing of a financial news article prediction system, AZFinText, with sentiment analysis techniques. Their study revealed that news articles of a negative sentiment were easiest to predict in both price direction (50.9\% vs $50.4 \%$ without sentiment). The majority of the literature is concerned with how fast information is incorporated into prices. All event studies introduced so far, failed to evaluate the relative impact of the business related news. 


\section{Materials and Methods}

All news may or may not have an impact on stock price. To measure the impact of business news on stock price, the essential thing is to prove that business news has impact on the prices. The trading volumes and prices changed on the day of the event, a day before the event and it may be continued up to the third day (Morse (1981)). The first research question is

- Do business news have any impact?

The corporate announcements have very important impact on the individual investors. The Investment patterns get affected by the corporate announcement and that is reflected in the share price. The second research question is

- Do the business NEWS offer abnormal high return? And

- What is the impact of business NEWS on investors' decision?

The positive news and negative news create different sentiment for the investment decision. The sentiment analysis used to biramous the positive and negative news. Third research question is

- Is there any significant difference in price reaction due to positive news and negative news?

H0: There is no significant difference between AAR of positive and negative news.

\subsection{Research Methodology}

The overall analysis is divided into to two stages. In first step, the news information analyzed to find the sentiments. In second step, the impact of news information was found in terms of price changes. The News data analysis is able to provide interesting results to predict stock market forecasting. In this study, "news" means the news information available at moneycontrol.com under the heading of "Business News". The Business related news was collected from monyecontrol.com. The moneycontrol.com provide category wise (Business, Earning, Management Interviews, stock advice and Research report) company-specific historical news and allowed to view and download the news.

The news information was collected for the period of two years from May 2013 to May 2015. Top 5 companies according to the highest capitalization were selected and their business related news information was collected from the moneycontrol.com. The 5 companies are Coal India Ltd, Reliance Industries Ltd, HDFC bank Ltd, ONGC and Tata Consultancy Services. Total 392 Business NEWS were collected and 166 were analyzed. To avoid the overlapping and compounding effect the news were not analyzed if more than 1 news were flashed within 10 days.

The term "news analytics" covers the set of techniques, formulas, and statistics which are used to summarize and classify public sources of information (Das (2011). The news analysis can be made of text, content and context. The text analysis considered the word, documents, and phrases and convert news into information. The content analysis considered the text, images, time, sources, forms and format of text. It offers more valuable analysis then text analysis. In context analysis, it found the relationship between information items, like news board posting and news, 
source of news and news. If the news information analyzed properly it becomes easy to understand the past and predict the future. To get the sentiment of the news information, the collected news information was analyzed with wordstat software (Majdalany and Henderson (2013)). It offers the positive, negative and other content in terms of percentage. The $-2-0-2$, total 5 days event window was considered to find out the impact of the business news. Compare to the long horizon, the short horizon is quite reliable, (Kothari and Warner (2007)). The short duration also helped in avoiding the effects of overlapping of other news events in long duration. The impact of business news was classified as overall, only of positive news and of negative news.

The main reaction of news events generally were found on the event day (Schmitz (2007)). The pre-announcement window helped in finding the predicted effect before the business news and post announcement window helped in finding the impact of business news in terms of price change. The returns are calculated as the log difference of total return to shareholders (Sprenger and Welp (2011)). To find the excess return, abnormal returns are calculated around the event date. The concept of abnormal returns goes with the assumption that information is absorbed by the current market price (Serra, 2002).

The BSE Sensex 30 share Index has been used to calculate the daily market return. To avoid the influence of extreme values, the logarithm of the daily market return was applied to calculate market return and daily stock return.

$$
R m_{t}=\ln \left(\frac{P_{1}}{P_{0}}\right)
$$

Where,

$\mathrm{P}_{1}$ is the stock price/Sensex 30 on day $\mathrm{t}$ (today)

$\mathrm{P}_{0}$ is the stock price/Sensex 30 on day $\mathrm{t}-1$ (Previous day)

$$
R_{j t}=\ln \left(\frac{P_{1}}{P_{0}}\right)
$$

The Abnormal return is the difference between actual return and expected return. It can be calculated as

$$
A R_{j t}=R_{j t}-E\left(R_{j t}\right)
$$

The market model was used to calculate abnormal returns around the each event date. Total 252 days were considered to calculate Intercept, Slope- Beta and Error term.

Where,

$$
R_{j t}=\alpha_{j}+\beta_{j} R m_{t}+\varepsilon_{j t}
$$

$\mathrm{R}_{\mathrm{jt}}=$ the actual daily return on security $\mathrm{j}$ at day $\mathrm{t}$ 
$\alpha_{\mathrm{j}}=$ ordinary least squares intercept $\left[E\left(R_{j}\right)-\beta E\left(R m_{t}\right)\right]$

$\beta \mathrm{j}=$ stock sensitivity to market return/The slope coefficient

$\varepsilon_{\mathrm{jt}}=$ the error term for security $\mathrm{j}$ at day $\mathrm{t}$

$$
E\left(R_{j t}\right)=\alpha_{j}+\beta_{j} R m_{t}
$$

To test the significance of the abnormal returns, the abnormal return of each day of event window is divided by the standard error. If the value is greater than 1.96 at 0.05 confidence level, the abnormal return is statistically significant.

$$
\text { Sgnificant T test }=\left(\frac{A R_{j t}}{\varepsilon_{j t}}\right)
$$

The Cumulative Abnormal return was calculated to measure the general impact of the news.

$$
C A R=\sum_{i=1}^{k} A R
$$

The abnormal trading volume indicates the impact of the event. If on the news announcement date, change in volume is significant then it can be interpreted that, news has an impact on the stock prices. Surprisingly the volume increased on the announcement and remained above average for the next few days Frazzini \& Lamont (2007). The relationship among trading volume around earnings announcements was investigated by Lerman, Livnat, \& Mendenhall (2008). They estimated the earnings announcement volume by dividing the average volume of -1 to 1 day by the average daily share volume estimated over days -8 to -63 days. They found that bad news showed a stronger immediate price response and a weaker drift (greater negative immediate returns, but less negative subsequent returns) and good news showed a stronger immediate stock price response and a stronger subsequent drift (greater positive immediate returns and greater positive drift). In this research study, the percentage change in volume is applied to measure the impact of NEWS. The percentage change in volume is calculated for the 5 days $(-2,0,+2)$. To check the $\%$ change in volume simple return equation was applied.

$$
\% \text { Change in Volume }=\frac{\operatorname{Vol}_{\text {Day1 }}-\operatorname{Vol}_{\text {Day0 }}}{\operatorname{Vol}_{\text {Day } 0}}
$$

\section{Results and Discussions}

\section{Research question 1 (Market Reaction to the NEWS)}

To check the impact of business news on investors' decision, total 392 news of 5 companies were collected and 166 news were analyzed (Table-1). 
Table 1: NEWS Details

\begin{tabular}{|l|l|l|l|l|l|l|l|l|l|l|}
\hline \multirow{2}{*}{ Year } & \multicolumn{2}{l|}{ Coal India } & \multicolumn{3}{l|}{ HDFC Bank } & \multicolumn{2}{l|}{ ONGC } & \multicolumn{2}{l|}{ Reliance } & TCS \\
\cline { 2 - 11 } & $\begin{array}{l}\text { Collec } \\
\text { ted }\end{array}$ & $\begin{array}{l}\text { Anal } \\
\text { yzed }\end{array}$ & $\begin{array}{l}\text { Collect } \\
\text { ed }\end{array}$ & $\begin{array}{l}\text { Analy } \\
\text { zed }\end{array}$ & $\begin{array}{l}\text { Collec } \\
\text { ted }\end{array}$ & $\begin{array}{l}\text { Analy } \\
\text { zed }\end{array}$ & $\begin{array}{l}\text { Collec } \\
\text { ted }\end{array}$ & $\begin{array}{l}\text { Analy } \\
\text { zed }\end{array}$ & $\begin{array}{l}\text { Collec } \\
\text { ted }\end{array}$ & $\begin{array}{l}\text { Analy } \\
\text { zed }\end{array}$ \\
\hline 2013 & 35 & 16 & 6 & 6 & 27 & 13 & 66 & 19 & 23 & 13 \\
\hline 2014 & 22 & 13 & 18 & 13 & 31 & 20 & 71 & 26 & 25 & 13 \\
\hline 2015 & 12 & 08 & 6 & 6 & 22 & 4 & 10 & 8 & 18 & 8 \\
\hline $\begin{array}{l}\text { Total } \\
\text { News }\end{array}$ & 69 & 37 & 30 & 25 & 80 & 37 & 147 & 53 & 66 & 34 \\
\hline
\end{tabular}

Firstly, the percentage change in volume is applied to check the impact of news. The volume is also classified for positive and negative news. The volume changed was fitted in time-plot (Figur-1) to check the impact of news. The spike in volume was observed on the day of the information introduced into the market. The volume started to increase before the event and spiked on the event day and after the event, volume goes down. The same impact can be observed in positive news (Figure - 2). But, the negative news reacted in reverse, day before the event volume went down, on the event day volume went up and then fell down (Figure - 3). The major movement in positive and negative news has been observed on the event day and on $2^{\text {nd }}$ day of the event which support the findings of Morse (1981). So, major difference in volumes traded around the earnings announcement date was observed. This indicates that the business news does have influence.

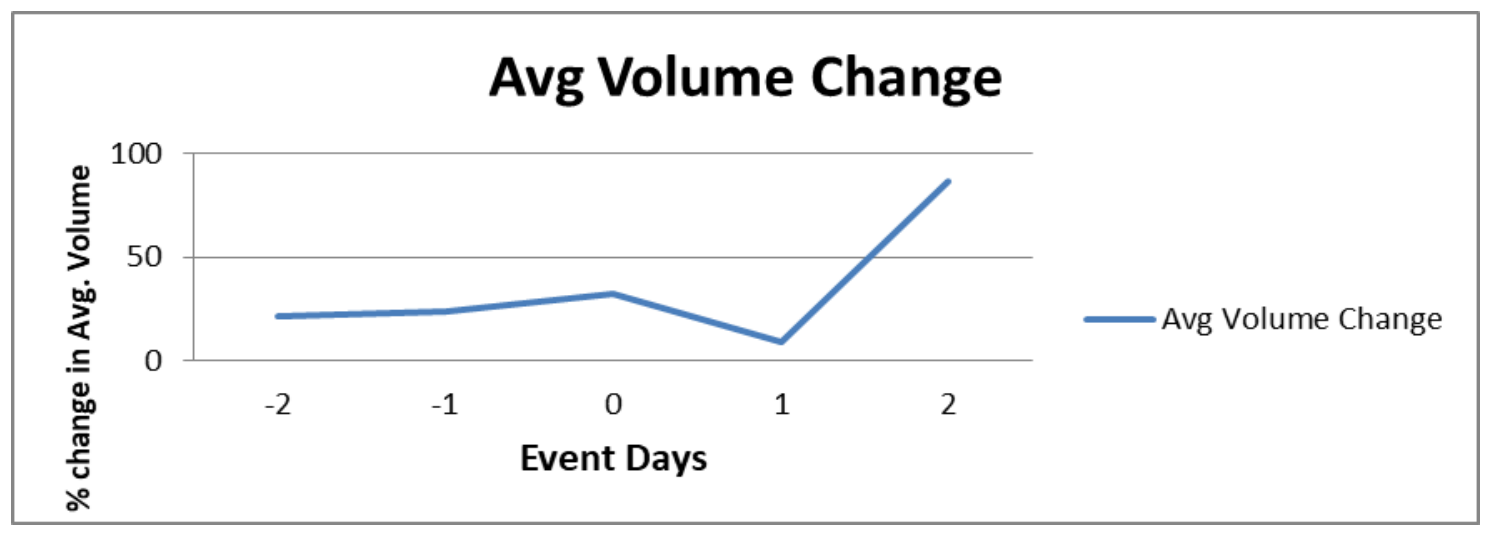

Figure 1

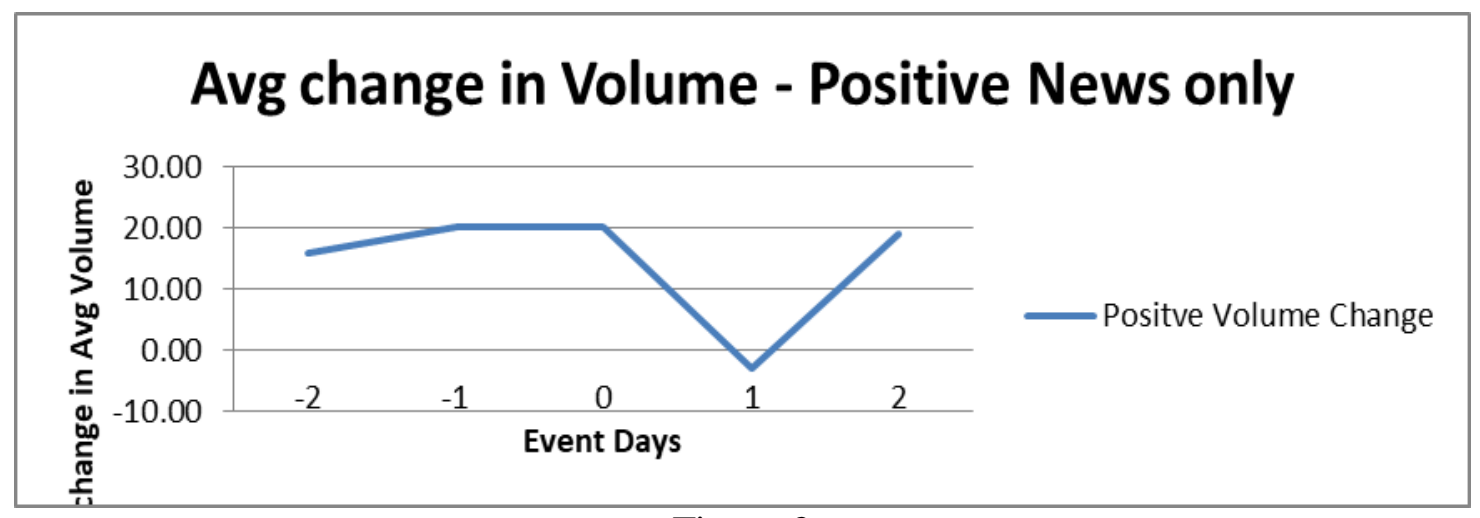

Figure 2 


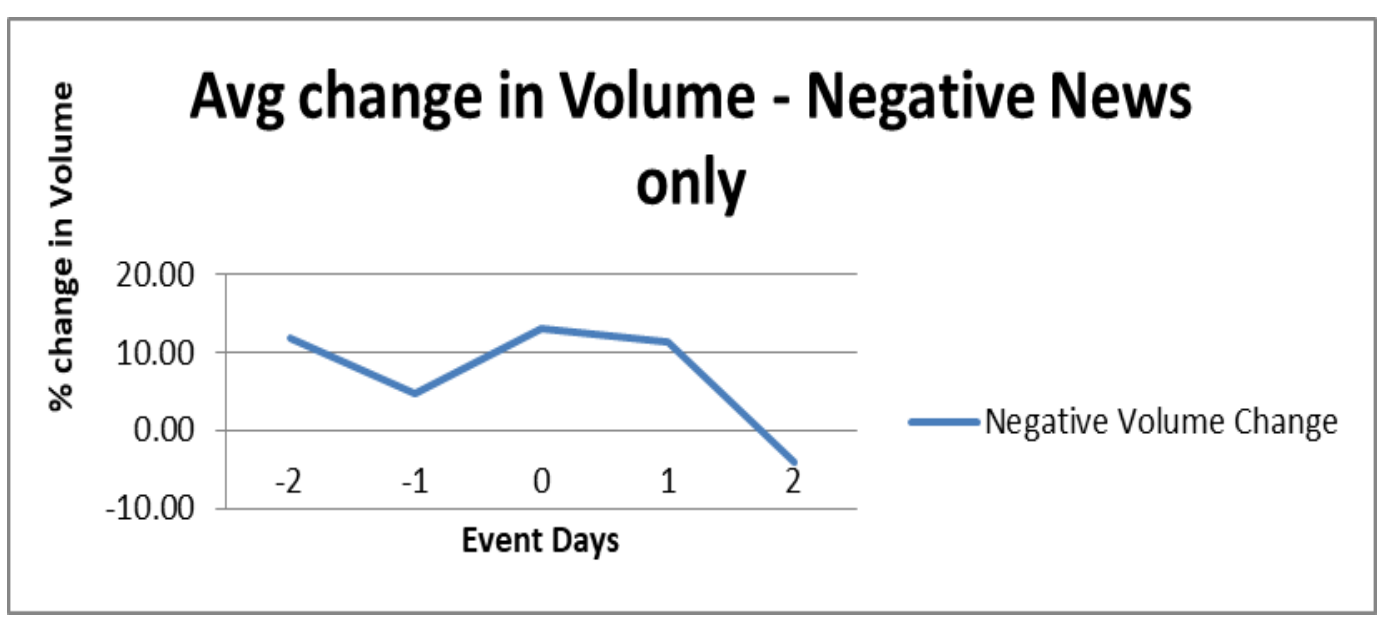

Figure 3

Research question 2: For the second research question, the market model was applied to calculate the AAR and CAAR. To test for significance, the t-statistics for the AR were obtained and compared to the t-table values at $5 \%$ level of significance. The AAR was obtained from the calculated AR. The calculated AAR was fitted in a time plot to establish the trends. Most of the AAR were positive before the event date while the AAR after the event date were negative (Figure 4). The finding is in contrast of Kiremu, Galo, Wagala, \& Mutegi (2013). The high positive abnormal return was observed on 1 day before the event day however not significant. This can be due to profit booking at higher AAR which could cause decline in AAR. The AAR was not significant before the event and after the event except for day 2 (Table 1). The result suggests that, the business news information is efficiently absorbed in the Indian market and did not generate statistically high abnormal return.

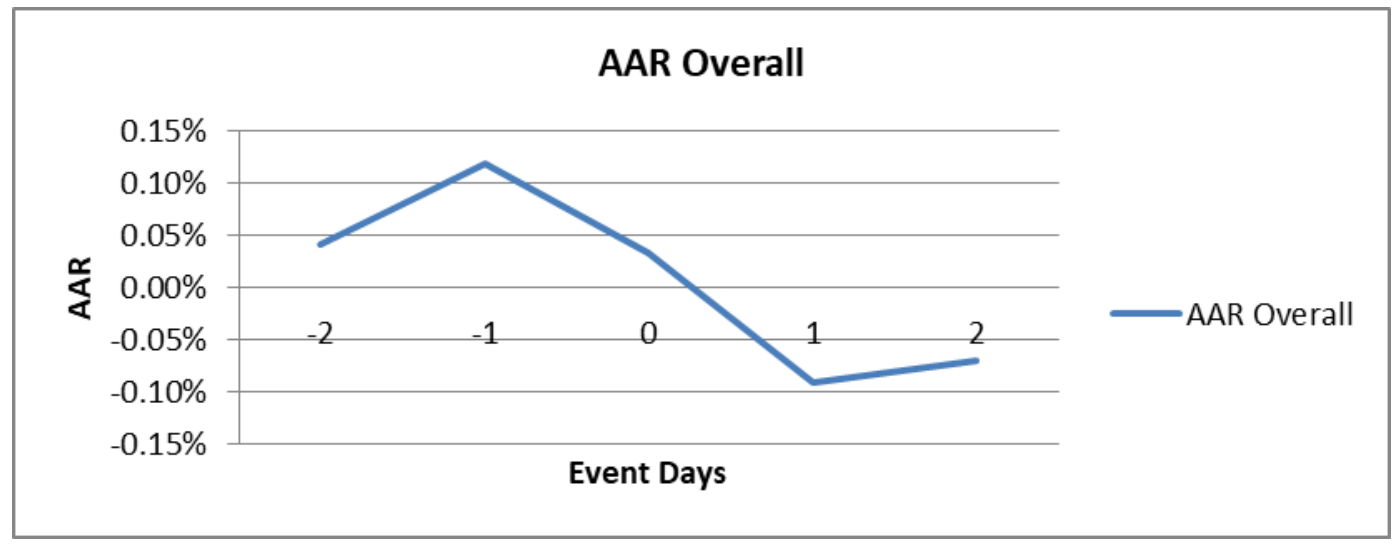

Figure 4

The CAAR start rising from day -2 up to the event day (Figure 5) and then after it starts to decline. It can be attributed to the fact that AR also follows the same pattern. The higher CAAR before the event indicate that news was released to small group of investors before the public announcement which is against of EMH. The informed investor can earn abnormal high return. So, the business news impacts the investors' decision. The CAAR was declined after the event day which indicates overreaction of the investors for the news. The CAAR was not significant before the event and after the event except for day 2 (Table 1). 
Table 1: Table Showing the Abnormal Returns and the T-Statistics for the 5 Days Event Window

\begin{tabular}{|l|l|l|l|l|l|l|}
\hline Event Days & AAR & STD Devi & T-stat AAR & CAAR & STD Devi & T-stat CAAR \\
\hline-2 & $0.04 \%$ & 0.00298 & 0.3124 & $0.04 \%$ & 0.00298 & 0.3140 \\
\hline-1 & $0.12 \%$ & 0.00256 & 1.0379 & $0.05 \%$ & 0.00274 & 0.3881 \\
\hline 0 & $0.03 \%$ & 0.00305 & 0.2447 & $-0.02 \%$ & 0.00267 & -0.1873 \\
\hline 1 & $-0.09 \%$ & 0.00342 & -0.5953 & $-0.08 \%$ & 0.00139 & -1.3199 \\
\hline 2 & $-0.07 \%$ & 0.00076 & $* \mathbf{- 2 . 0 2 5 8}$ & $-0.16 \%$ & 0.00118 & $*-2.9566$ \\
\hline
\end{tabular}

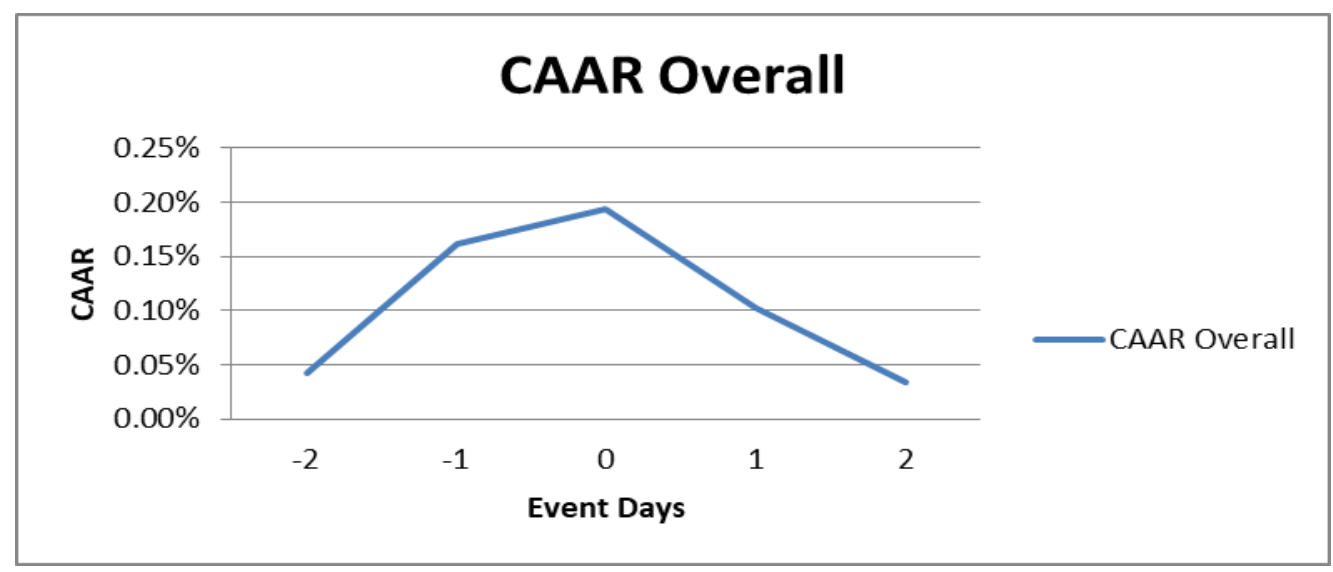

Figure 5

Research question 3: The investors reacted differently towards positive and negative business news (figure 6 and 7). The positive news and negative news offered high abnormal return on day -1 and day 0 . The positive news offered higher abnormal return before the event compare to negative return which support Sprenger and Welp (2011). The negative news showed high negative return compared to positive news on day +1 which supports Lerman \& all (2008). The AAR of positive and negative news was not significant before the event and after the event (Table 2). The company specific business news were analyzed but no AAR was significant except for ONGC day +1 and for Coal India day -2 (Table 3$)$. The null hypothesis $\left(\mathrm{H}_{0}\right)$ was accepted and concluded that there is no significant difference between AAR of positive and negative news (Table 4).

Table 2: Table Showing the Abnormal Returns and the T-Statistics for the 5 Days Event Window of Positive and Negative News

\begin{tabular}{|l|l|l|l|l|l|l|}
\hline $\begin{array}{l}\text { Event } \\
\text { Days }\end{array}$ & $\begin{array}{l}\text { Positive } \\
\text { AAR }\end{array}$ & $\begin{array}{l}\text { STD } \\
\text { Devi }\end{array}$ & $\begin{array}{l}\text { T-Stat Positive } \\
\text { News }\end{array}$ & $\begin{array}{l}\text { Negative } \\
\text { AAR }\end{array}$ & $\begin{array}{l}\text { STD } \\
\text { Devi }\end{array}$ & $\begin{array}{l}\text { T-Stat Negative } \\
\text { News }\end{array}$ \\
\hline-2 & $0.13 \%$ & 0.0038 & 0.7646 & $-0.21 \%$ & 0.0047 & -1.0211 \\
\hline-1 & $0.26 \%$ & 0.0058 & 0.9922 & $0.24 \%$ & 0.0043 & 1.2307 \\
\hline 0 & $0.31 \%$ & 0.0057 & 1.2096 & $0.24 \%$ & 0.0056 & 0.9644 \\
\hline 1 & $0.07 \%$ & 0.0038 & 0.4408 & $-0.03 \%$ & 0.0113 & -0.0593 \\
\hline 2 & $0.04 \%$ & 0.0026 & 0.3590 & $0.22 \%$ & 0.0058 & 0.8533 \\
\hline
\end{tabular}


Table 3: Table Showing the Abnormal Returns and the T-Statistics for the 5 Days Event Window of Company specific Business News

\begin{tabular}{|c|c|c|c|c|c|c|}
\hline Company Name & \multirow{2}{*}{ Detail } & \multicolumn{5}{|c|}{ Event Days } \\
\cline { 3 - 7 } & & -2 & -1 & 0 & 1 & 2 \\
\hline \multirow{3}{*}{ ONGC } & AAR & $-0.13 \%$ & $0.03 \%$ & $0.48 \%$ & $-0.68 \%$ & $0.04 \%$ \\
\cline { 2 - 7 } & STD Devi & 0.0172 & 0.0188 & 0.0177 & 0.0164 & 0.0185 \\
\cline { 2 - 7 } & T-Statistic & -0.4629 & 0.0821 & 1.6593 & $-2.5314 *$ & 0.1290 \\
\hline \multirow{3}{*}{ Coal India } & AAR & $0.57 \%$ & $0.52 \%$ & $-0.16 \%$ & $0.02 \%$ & $-0.10 \%$ \\
\cline { 2 - 7 } & STD Devi & 0.0159 & 0.0175 & 0.0203 & 0.0170 & 0.0143 \\
\cline { 2 - 7 } & T-Statistic & $2.1653 *$ & 1.7996 & -0.4669 & 0.0862 & -0.4095 \\
\hline \multirow{3}{*}{ HDFC Bank } & AAR & $0.0046 \%$ & $-0.1886 \%$ & $0.1213 \%$ & $0.0556 \%$ & $-0.0349 \%$ \\
\cline { 2 - 7 } & STD Devi & 0.0100 & 0.0086 & 0.0088 & 0.0061 & 0.0065 \\
\cline { 2 - 7 } & T-Statistic & 0.0227 & -1.1022 & 0.6914 & 0.4537 & -0.2700 \\
\hline & AAR & $-0.10 \%$ & $0.09 \%$ & $-0.32 \%$ & $0.20 \%$ & $-0.17 \%$ \\
\cline { 2 - 7 } & STD Devi & 0.009 & 0.011 & 0.012 & 0.014 & 0.011 \\
\cline { 2 - 7 } & T-Statistic & -0.812 & 0.588 & -1.856 & 1.025 & -1.064 \\
\hline \multirow{3}{*}{ TCS } & AAR & $-0.13 \%$ & $0.15 \%$ & $0.04 \%$ & $-0.05 \%$ & $-0.09 \%$ \\
\cline { 2 - 7 } & STD Devi & 0.0131 & 0.0118 & 0.0110 & 0.0198 & 0.0134 \\
\cline { 2 - 7 } & T-Statistic & -0.5638 & 0.7304 & 0.2263 & -0.1530 & -0.3834 \\
\hline
\end{tabular}

Table 4: Table Showing the T-Statistics for the AAR of positive and negative news

\begin{tabular}{|l|l|l|}
\hline Company Name & \multicolumn{2}{|l|}{ Detail (a=0.05) } \\
\hline \multirow{4}{*}{ ONGC } & T-Statistic & 0.586901773 \\
\cline { 2 - 3 } & P Value & 0.573454907 \\
\cline { 2 - 3 } Coal India & H0 & Accept \\
\hline \multirow{5}{*}{ HDFC Bank } & T-Statistic & -0.228848005 \\
\cline { 2 - 3 } & P Value & 0.8247288 \\
\cline { 2 - 3 } & H0 & Accept \\
\hline Reliance Industries & T-Statistic & 0.424186087 \\
\cline { 2 - 3 } & P Value & 0.682606515 \\
\cline { 2 - 3 } & H0 & Accept \\
\cline { 2 - 3 } & P Value & 0.624616708 \\
\cline { 2 - 3 } & H0 & Accept \\
\hline TCS & T-Statistic & 0.673306829 \\
\cline { 2 - 3 } & P Value & 0.519725548 \\
\cline { 2 - 3 } & H0 & Accept \\
\hline
\end{tabular}




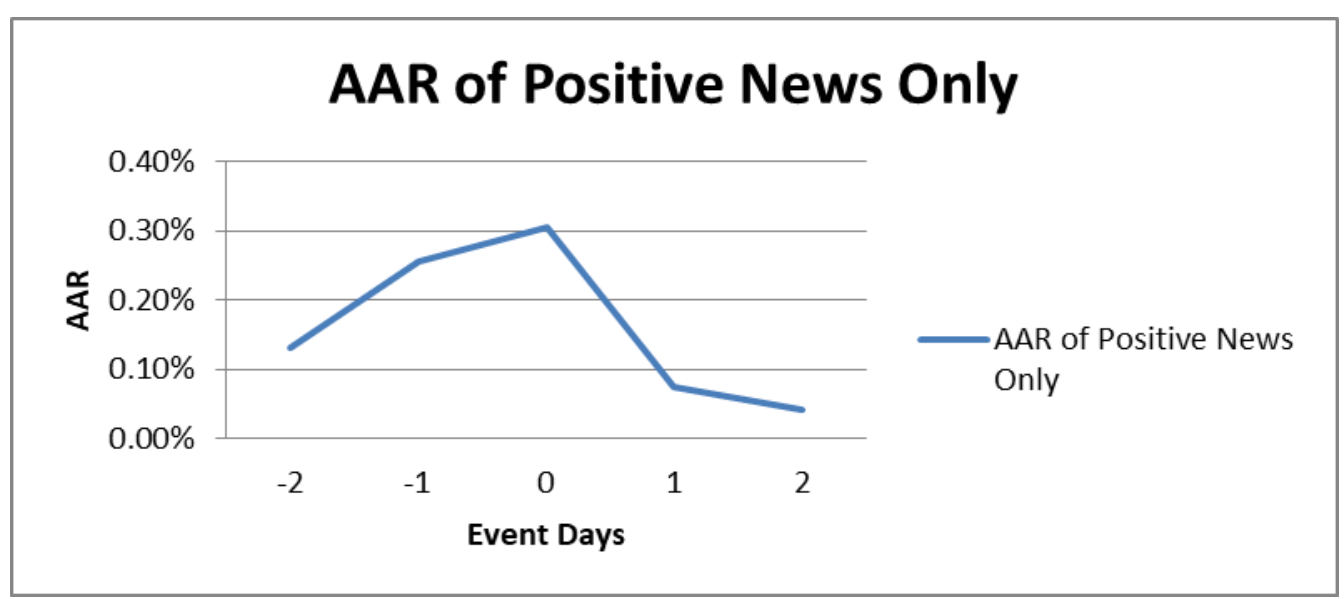

Figure 6

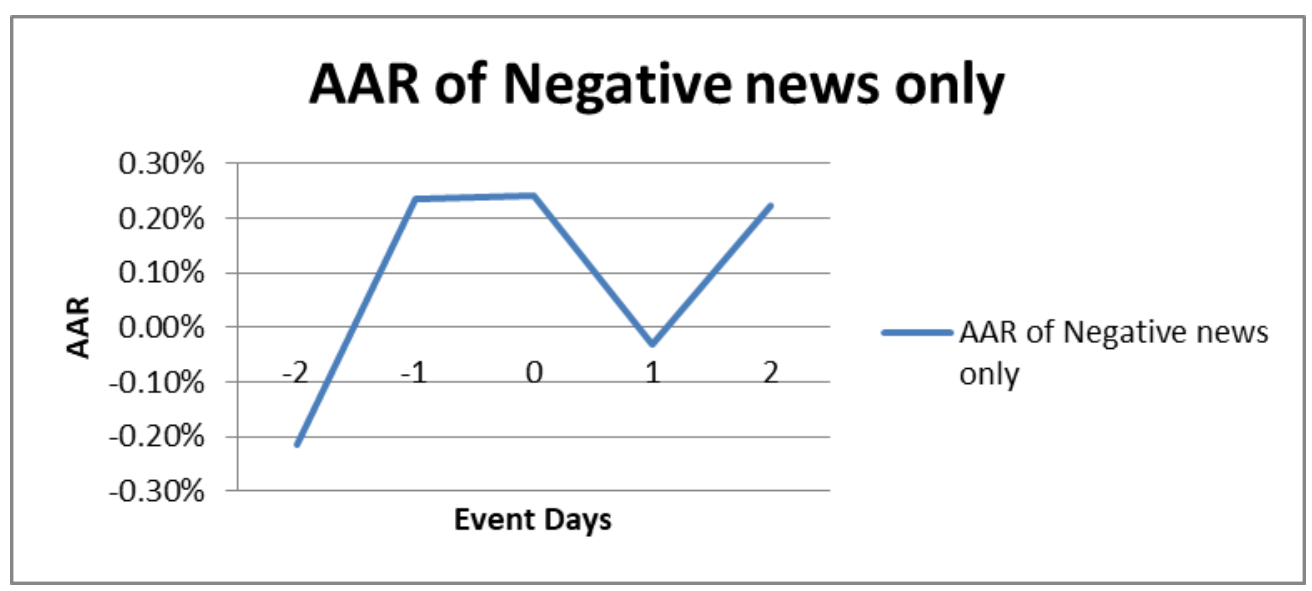

Figure 7

\subsection{Conclusion and Scope for Future Work}

The aim of study was to study impact of business news on investors' decision. The whole study and analysis was classified into 3 research questions. Firstly, the news impact was measured by the volume behavior during the event window of 5 days. The abnormal change in volume was observed on the day of the information introduced into the market. The volume started to increase before the event and sparked on the event day. And after the event, volume goes down. So, the conclusion is that Business news has impact on investors' decision.

Secondly, to test for significance, the t-statistic for the AAR and CAAR were obtained and compared to the t-table values at 5\% level of significance. The high abnormal return was observed on 1 day before the event day. The AAR was not significant before the event and after the event except for day 2 (Table 1). The result suggests that, the business news information is efficiently absorbed in the Indian market and did not generate statistically high abnormal return. The CAAR was also not significant before the event and after the event except for day 2. It can be interpreted that before the event the investors predict positive announcement. The informed investor can buy/sell the shares as per news and can earn abnormal high return. The CAAR was declined after the event day which indicates overreaction of the investors for the news. 
Thirdly, the AAR of positive and negative news ware compared to study the investors' behavior for the positive and negative news. There is no any significant difference among AAR of positive and negative news. So, it can state that news sentiment analysis does not offer abnormal higher return. But according to the figure 4 investors can earn abnormal return on the event day. This study can bring some improvement and untried ideas for the future work.

In this study, business news of only 5 companies were covered, this study can include all 50 companies of Nifty or 30 companies of BSE.

The study is limited to only 2 year. The researcher can cover news for more than 2 years. The researcher can also study news of earning announcement, management interview and researchers' recommendation.

The event window period is of 5 days. To study the impact of major headlines the event window can be extended from 30 days to 120 days.

The Expected return was calculated through market model. The other model like CAPM can give broader view.

\section{References}

[1] Adrian Wai Kong Cheung. (2011). "Do Stock Investors Value Corporate Sustainability? Evidence from an Event Study". Springer Journal of Business Ethics (2011) 99:145-165

[2] Afego, P. (2011). Stock Price Response to Earnings Announcements: Evidence from the Nigerian Stock Market. University of Dundee, DD1 4HN, United Kingdom: Unpublished.

[3] Angela K. Davis, Jeremy M. Piger and Lisa M. Sedor. (2006). "Beyond the Numbers: An Analysis of Optimistic and Pessimistic Language in Earnings Press Releases". http://www.cis.upenn.edu/ mkearns/finread/optimistic.pdf

[4] B. Pang and L. Lee, "Opinion Mining and Sentiment Analysis", Foundations and Trends in Information Retrieval (2, 1-2), 2008, pp. 1-135.

[5] Calum Robertson, Shlomo Geva and Rodney Wolff, (2006). "What Types of Events Provide the Strongest Evidence that the Stock Market is Affected by Company Specific News?" Australasian Data Mining Conference (AusDM 2006), Sydney, December 2006. Conferences in Research and Practice in Information Technology, Vol. 61.

[6] Fama, Eugene F. 1991. "Efficient capital markets: II. Journal of Finance 46(5) 1575-1617."

[7] Frazzini, A., \& Lamont, O. A. (2007). The earnings announcement premium and trading volume. NBER Working Paper, (w13090). Retrieved from http://papers.ssrn.com/sol3/papers.cfm?abstract_id=986940

[8] George Majdalany and Jeffrey Henderson, (2013). "Voluntary Disclosure of Intellectual Assets and Intellectual Liabilities: Impact on Financial Performance in Publicly Listed Firms in the United Arab Emirates". Electronic Journal of Knowledge Management Volume 11 Issue 42013

[9] Gidofalvi, Gyozo. "Using News Articles to Predict Stock Price Movements". Department of Computer Science and Engineering, University of California, San Diego, 2001.

[10] Jasmina Smailovic., Miha Grcar., Nada Lavrac and Martin Znidarsic. (2014). "Stream-based active learning for sentiment analysis in the financial domain". Information Sciences 285 (2014) 181-203.

[11] Katz, S.B. (2001). "Language and persuasion in biotechnology communication with the public: How not to say what you're not going to say and not say it". AgBioForum 4 (2): 93-97. 
[12] Kiremu, M. K. G., Galo, N., Wagala, A., \& Mutegi, J. K. (2013). Stock Price and Volumes Reaction to Annual Earnings Announcement: A Case of the Nairobi Securities Exchange. International Journal of Business, Humanities and Technology, 3(2), 101-111.

[13] Kothari, S. P., Jerold B. Warner. 2006. "The econometrics of event studies. B. Espen Eckbo, ed., Handbook in Empirical Corporate Finance. North-Holland, Amsterdam, forthcoming."

[14] Lerman, A., Livnat, J., \& Mendenhall, R. R. (2008). The high-volume return premium and postearnings announcement drift. Available at SSRN 1122463. Retrieved from http://papers.ssrn.com/sol3/papers.cfm?abstract_id=1122463

[15] Michael Siering. 2012. "Boom" or "Ruin" - Does it Make a Difference? Using Text Mining and Sentiment Analysis to Support Intraday Investment Decisions". 45th Hawaii International Conference on System Sciences. 978-0-7695-4525-7 (C) 2012 IEEE.

[16] Morse, D. (1981). Price and Trading Volumes Reaction Sorrounding Earning Announcements: A Closer Examination. Journal of Accounting Research, Vol. 19 (2), pp. 83-374.

[17] P. C. Tetlock, "Giving Content to Investor Sentiment: The Role of Media in the Stock Market", The Journal of Finance (62, 3), 2007, pp. 1139-1168.

[18] P. Srinivasan., 2010., "Does Indian Equity market follow random walks? Evidence from the National Stock Exchange." International Journal of Research in Commerce and Management, Vol: 1 (2010), Issue No. 8.

[19] Peter Ager Hafez., 2010. "How News Events Impact Market Sentiment." RavenPack International, S.L.

[20] Philipp Schmitz, P., 2007, “ Market and Individual Investors Reactions to Corporate News in Media." Working paper, University of Mannheim.

[21] Robert P. Schumaker, Yulei Zhang and Chun-Neng Huang (2008). "Sentiment Analysis of Financial News Articles".

[22] Sanjiv R. Das (2011). Ch-2 News analytics: Framework, techniques, and metrics. Handbook of NEWS Analytics. PP 44-45

[23] Sedor, L. (2002). “An explanation for unintentional optimism in analysts' earnings forecasts". The Accounting Review 77 (4): 731-753.

[24] Serra, A. P. (2002). Event Study Tests: A brief survey. Working papers PEP 117.

[25] Soon Yu Chiang., 2010. "News Which Moves the Market: Assessing the Impact Of Published Financial News On The Stock Market". Thesis submitted to Singapore Management University, UMI Number: 1494102.

[26] T. Loughran and B. McDonald, 2011. "When Is a Liability Not a Liability? Textual Analysis, Dictionaries, and 10-Ks", The Journal of Finance $(66,1), 2011$, pp. 35-65.

[27] Timmo O. Sprenger., Isabell M. Welp. January 2011. "News or Noise? The stock Market reaction to different types of company-Specific news events." http://ssrn.com/abstract=1734632

[28] Werner Antweiler., Murray Z. Frank. 2006. "Do U.S. Stock Markets Typically Overreact to Corporate News Stories?"

[29] Wenbin Zhang, 2011. "News Based Forecasting and Modeling". A Dissertation Presented to The Graduate School in Partial Fulfillment of the Requirements for the Degree of Doctor of Philosophy in Computer Science Stony Brook University.

\footnotetext{
*Corresponding author.

E-mail address: divyangpimr2014@gmail.com
} 